\title{
Interaksi Wisata Syariah dan Pembangunan Ekonomi di Kota Pusarnya Pulau Jawa dalam Bentuk Ekonomi Komersial Ganda
}

\author{
Endro Tri Susdarwono ${ }^{\mathrm{a}, 1}$ \\ ${ }^{a}$ Universitas Peradaban, Jalan Raya Pagojengan KM 3 Paguyangan, Brebes 52212, Indonesia \\ ${ }^{1}$ saniscara99midas@gmail.com*) \\ * corresponding author
}

Article history:

Received: October 15, 2020

Reviewed: November 5, 2020

Accepted: November 25, 2020

Published: December 21, 2020

Keyword: Dual commercial economy, economic development, interaction, sharia tourism

The purpose of this study is to discuss the relationship or interaction between Islamic tourism and economic development in Pemalang Regency in the form of a double commercial economy. This research is a qualitative research, the type of research uses a comprehensive analytical study and analytical normative approach. Sharia tourism must be understood as a religious and cultural concept, in which Islamic objectives, Islamic teachings, as well as Islamic principles and practices must be included and made into the programs offered in these Sharia tourism activities. This means that Sharia tourism is not only for moving the activities of tourists to our area, but also for offering them our religious and cultural values. This conceptualization of Sharia tourism interactions is summarized in three main points: economy, culture and religion. Tourism is of course aimed as a business world that is halal and brings financial benefits to Muslims. Tourism can also be used as a medium to promote and introduce Islamic cultures. Finally, the interest of Islamic tourism is to spread Islamic values and teachings.

Copyright () 2019 Politeknik Negeri Samarinda. All rights reserved.

\section{Pendahuluan}

Pariwisata merupakan salah satu sektor yang sangat potensial dalam memberikan kontribusi untuk meningkatkan perekonomian suatu negara [1]. Pengembanagan pariwisata Syariah juga dapat menumbuhkan industri pendukung lain, sehingga dapat membangun integrasi baik antar sektor pariwisata ataupun dengan sektor lain di suatu wilayah [2].

Industri pariwisata salah satu investasi bisnis yang bisa mendatangkan keuntungan dan kesejahteraan bagi masyarakat. Hal ini karena dengan adanya pariwisata, akan membuka lebih banyak lapangan pekerjaan. Selain itu juga bisa memberikan motivasi bagi setiap individu untuk berkreasi dan berinovasi. Mengembangkan industri pariwisata yang berbasis syariah juga merupakan sebuah kontribusi untuk lebih mengembangkan dan menerapkan konsep ekonomi syariah. Syariah tidak hanya untuk perbankan, tetapi apapun bentuk transaksi ekonomi dan bisnis selain perbankan juga perlu dikembangkan berdasarkan konsep Syariah [3]. Konsep ini diyakini muncul dari nilai-nilai Islam dan kearifan lokal yang dicampur menjadi suatu tujuan pariwisata. Dengan tidak menghilangkan esensi dari lokasi pariwisata yang sejatinya tidak Islami, tetapi sebenarnya dapat meningkatkan nilai jual dan ketertarikan bagi paket perjalanan pariwisata [4].

Pariwisata halal merupakan salah satu sektor dalam Ekonomi Islam yang mengalami perkembangan yang signifikan. Pada tahun 2015, sumbangan terhadap pasar pariwisata dunia dari masyarakat muslim dunia mencapai US\$ 151 milyar dan diprediksikan akan menembus US\$243 milyar di tahun 2021 [5]. Sektor pariwisata memainkan peranan penting dalam ekonomi dunia karena dianggap sebagai salah satu kontributor pertumbuhan lapangan kerja dan 
pertumbuhan ekonomi di negara manapun.Sehingga pariwisata dapat pula dipandang sebagai salah satu sumber paling penting bagi Produk Domestik Bruto (PDB) [6].

Prinsip yang digunakan dalam wisata syariah adalah untuk memastikan keamanan untuk konsumen dengan menekankan nilai kejujuran, integritas, dan menghormati budaya lokal. Ada lima komponen yang dimasukkan dalam wisata syariah oleh Kemamenparekraf dan MUI yaitu sektor kuliner, fashionmuslim, perhotelan dan akomodasi, kosmetik dan spa, serta haji umrah. Jadi wisata syariah saat ini tidak hanya pada peninggalan sejarah Islam, ziarah kubur dan sejenisnya saja. Hal ini merupakan potensi besar yangdimiliki Indonesia yang hasil digarap secara maksimal [7].

Terkait dengan deskripsi wilayah, Kabupaten Pemalang merupakan bagian dari wilayah Provinsi Jawa Tengah, posisi Pemalang terletak di pantai utara Pulau Jawa. Kabupaten Pemalang dikenal sebagai pusarnya Pulau Jawa, kabupaten ini memiliki batas-batas sebagai berikut: di sebelah Utara berbatasn dengan Laut Jawa, di Selatan berbatasn dengan Kabupaten Purbalingga, di sebelah Timur berbatasam dengan Kabupaten Pekalongan, dan di sebelah Barat berbatasan dengan Kabupaten Tegal.

Potensi wisata Kabupaten Pemalang terbentang mulai berupa pantai sampai gunung. Potensi obyek wisata terdiri dari obyek yang merupakan langsung dari alam maupun buatan, disamping itu di Pemalang terdapat puluhan obyek wisata yang tergolong obyek wisata Syariah. Semua potensi yang ada dikembangkan besama baik melalui campur tangan Pemerintah Desa sampai Kabupaten Pemalang termasuk juga tidak ketinggalan masyarakat yang tergolong dalam masyarakat kelompok sadar wisata (pokdarwis).

Wisata Syariah dapat didefinisikan sebagai, "upaya perjalanan atau rekreasi untuk mencari kebahagiaan yang tidak bertentangan dan menyalahi prinsip-prinsip ajran Islam, serta sejak awal diniatkan untuk mengagumi kebesaran ciptaan Allah. Selain itu, perjalanan dengan tujuan tertentu juga diniatkan sebagai sebuah perjalanan syiar, setidaknya dengan melafalkan ayat-ayat suci, atau bertasbih mengagumi keindahan alam sekitar, dan amalan positif lainnya yang sesuai dengan ajaran Islam serta memberi manfaat bagi kehidupan umat manusia dan lingkungan sekitar."

Dengan cara demikian, maka bukan saja target dan tujuan wisata Syariah tercapai, tapi juga menunjukkan, khususnya kepada kalangan non-muslim, bahwa syariat Islam memiliki prinsip-prinsip yang universal dan menentramkan banyak kalangan. Syariat Islam tidaklah seperti anggarapn sementara pihak, terutama kalngan dunia Barat yag menggambarkan sebagai hukum yang kejam dan tidak manusiawi. Justru syariat Islam melindungi dan memberikan rahmat bagi sekalian alam.

Dalam konteks wisata Syariah, tentu saja, banyak sekali objek-objek wisata di Indonesia terutama jika dikaitkan dengan daerah-daerah yang kaya akan objek wisata Syariah. Karena itulah, pengembangan wisata syariah merupakan sebuah keniscayaan yang tidak dapat dipungkiri. Arah pengembangan pariwisata Islam tersebut ditujukan untuk memberikan pelayanan dan kepuasan batin kepada para wisatawan pada mumnya maupun wisatawan muslim khususnya. Apabila nilai-nilai normatif maupun historis Islam terwakili oleh atau dalam objek-objek wisata yang ditawarkan, maka otomatis wisata Syariah sudah terbentuk [8].

Penelitian ini bermaksud memberikan gambaran bagaimana interaksi antara wisata syarian dan pembangunan ekonomi yang diwujudkan dalam bentuk efek ekonomi komersial ganda dengan studi kasus di Kabupaten Pemalang.

\section{Review Tinjauan Pustaka}

Pariwisata menurut United Nation World Tourism Organitazation yaitu meliputi berbagai kegiatan yang dikerjakan oleh orang yang mengadakan kunjungan dan bermukim di suatu daerah di luar area yang biasa selama waktu yang tidak lebih dari satu tahun secara berulang-ulang guna rekreasi, kegiatan bisnis dan tujuan lainnya [9].

Wisata syariah dapat diartikan sebagai proses penggabungan nilai-nilai keislaman ke dalam seluruh aspek kegiatan wisata. Saat ini pariwisata syariah sedang menjadi tren, 
konsep syariah merupakan jawaban dari tingginya untapped market yang belum tersentuh dengan maksimal [10].

Terminologi wisata syariah di beberapa negara ada yangmenggunakan istilah seperti Islamic tourism, halal tourism, halal travel, ataupun as moslem friendly destination. Selain istilah wisata syariah, dikenal juga istilah halal tourism atau wisata halal. Definisi pariwisata syariah adalah kegiatan yang didukung oleh berbagai fasilitas serta layanan yang disediakan masyarakat, pengusaha, pemerintah, dan pemerintah daerah yang memenuhi ketentuan Syariah [11].

Kriteria umum pariwisata syariah ialah: 1 . Memiliki orientasi kepada kemaslahatan umum; 2. Memiliki orientasi pencerahan, penyegaran, dan ketenangan; 3. Menghindari kemusyrikan dan khurafat; 4. Bebas dari maksiat; 5. Menjaga keamanan dan kenyamanan; 6. Menjaga kelestarian lingkungan; 7. Menghormati nilai-nilai sosial budaya dan kearifan lokal [12].

Teori dualism ekonomi kontinum [13] menjelaskan hubungan antara sektor ekonomi tradisional dengan sektor ekonomi modern merupakan hubungan fungsional. Karena sektor ekonomi modern merupakan kelanjutan dari sector ekonomi tradisional. Oleh sebab itu hubungan fungsional antara sector ekonomi tradisional dengan sector ekonomi modern bersifat saling menguntungkan kedua sector ekonomi tersebut (mutualisme). Hubungan fungsional antara kedua sector ekonomi menghasilkan suatu kondisi dinamis yang mampu merubah unit usaha ekonomi tradisional menjadi ekonomi modern.

\section{Metodologi Penelitian}

Metode sebagai alat kerja lebih ditekankan kepada cara kerja pikiran dalam rangka memahami objek penelitian. Teknik dipandang sebagai cara kerja untuk melakukan atau menangkap hasil cara kerja pikiran (metode). Pendekatan dalam penelitian ini menggunakan pendekatan deskriptif, pendekatan tersebut dimaksudkan untuk memaparkan atau menggambarkan keterkaitan atau interaksi antara wisata Syariah dengan pembangunan ekonomi di Kabupaten Pemalang dalam bentuk ekonomi komersia ganda, sedangkan jenis penelitian adalah penelitian deskriptif kualitatif, yaitu mendeskripsikan dan menginterpretasi apa yang ada, itu dapat mengenai kondisi/hubungan yang ada. Pendapat yang sedang tumbuh, proses yang sedang berlangsung, akibat/efek yang tejadi atau kecenderungan yang tengah berkembang.

\section{Hasil dan Diskusi}

Indonesia memiliki banyak kota bersejarah dan pemandangan alam yang indah menawan. Ini hanyalah sekadar contoh kecil tentang kemungkianan pengembangan objek-objek wisata berbasis norma dan etika agama atau yang kita istilahkan dengan wisata Syariah. Tentu saja, potensi komersial pasar perjalanan (tourism) berbasis keagamaan ini telah banyak disorot dan dibicarakan negara-negara muslim. Wisata Syariah diprediksi akan semakin terkenal, baik di negara-negara muslim maupun di seluruh dunia. Wisata Syariah bukanlah satu jenis pariwisata, dalam kasus pariwisata sekuler. Sebab, sebagaimana dikatakan sebelumnya, wisata Syariah ini memperhatikan motif-motif dan nilai-nilai agama Islam, sehingga segala bentuk objek wisata yang ditawarkan sampai berbagai jenis pelayanan jasanya, dipastikan sesuai dengan aturan-aturan yang Islami dan tidak melanggar larangan-larangan agama.

Sekedar contoh yang layak disebutkan bahwa, wisata Syariah tidak akan menyediakan tempat-tempat hiburan yang bertentangan dengan syariat agama, seperti tempat hiburan malam yang penuh dengan alcohol dan hubungan-hubungan bebas antara laki-laki dan perempuan, serta aktivitas maupun hiburan lain yang mengundang syahwat maupun mengandung unsur kemaksiatan. Berbeda dengan wisata sekuler, dimana Hasrat nafsu betul-beul dimanjakan sedemikian rupa, sehingga manusia nyatanyata tidak lagi terkontrol oleh norma agama.

Meski tidak lepas dari persoalan prokontra pemikiran, pengembangan wisata Syariah (Syariah Tourism) membutuhkan konseptualisasi yang matang, kea rah mana pengembangannya, apa tujuannya, dan visimisi apa yang mau dicapai. Di sini bukan lagi pertarungan pendapat yang dibutuhkan melainkan dukungan dan kerja sama semua 
pihak guna mencapati tujuan yang disepakati dengan cara yang disetujui Bersama.

Selanjutnya, potensi wisata juga bisa bersifat nonmaterial. Potensi yang nonmaterial ini bisa berupa kebudayaan dan karakteristik bangsa. Umat Muslim Indonesia memiliki satu pontesi kultural yang pantas diperkenalkan ke dunia dan menjadi suri tauladan bagi dunia Muslim Indonesia adalah Musim yan santun, ramah, dan lembut, mampu hidup lebih harmonis dan damai Bersama orang-orang yang non-muslim. Semua itu adalah pontensi in material yng bisa dikembangkan dan menjadi objek wisata internasional.

Sebagai sebuah aktivitas kemasyarakatan, wisata Syariah tidak sekadar untuk mencari kebahagiaan material dan duniawi. Dengan karakternya yang khas, yakni harus sesuai dengan nilai-nilai Islam, sedari awal diniatkan sebagai upaya mengagumi ciptaan Allah sehingga dapat memperkuat keyakinan kita kepada Allah, wisata Syariah juga potensial menjadi wahana syiar agama kepada pihak lain. Syiar dalam konteks keharmonisan kehiduapan beragama, saling menghargai dan memupuk saling pengertian satu dengan lainnya.

Terkait dengan wisata Syariah di Pemalang, terdapat banyak objek wisata yang dijadikan tujuan utama wisatawan Nusantara. Teerdapat banyak makam orang yang diangap sebagai ulama ataupun tokoh yang dijadikan sebagai pedoman hidup. Makammakam yang seringkali dijadikan tujuan utama wisatawan misalnya Syekh Maulana Syamsuddin, Syekh Antasi, Sigeseng, dan makam-makam keramat lain. Lokasi makammakam tersebut tersebar di beberapa lokasi seperti di Desa Pesantren, Desa Kendal Rejo, Kecamatan Watu Kumpul, dan lokasi-lokasi lain. Terdapat juga banyak situs yang dianggap keramat seperti petilasan di Gunung Mendelem, petilasan ini sering menarik orang-orang yang mempunyai kepercayaan tertentu.

Pengembangan wisata Syariah juga merupakan kegiatan pengembangan masyarakat dan wilayah yang didasarkan pada: 1. Memajukan tingkat hidup masyarakat sekaligus melestarikan identitas local; 2. Meningkatkan tingkat pendapatan secara ekonomis serta pendistribusian merata kepada masyarakat; 3. Berorientasi kepada pengembangan wisata berskala kecil dan menengah dengan daya serap tenaga kerja besar dan berorientasi kepada teknologi kooperatif; 4. Memanfaatkan pariwisata seoptimal mungkin sebagai penyumbang tradisi negara.

Terkait konsep pengembangan wisata Syariah, penulis ingin mengutip pandangan Abdul-Sahib Al-Shakry. Beberapa konsep yang ditawarkannya, menurut hemat penulis, cukup untuk dijadikan pertimbangan awal konseptualisasi wisata Islam. Konsep wisata Syariah dalam pandangan Abdul-Sahib AlShakry harus memenuhi beberapa poin utama berikut ini: Pertama, kebangkitan budaya dan penyebaran nilai-nilai Islam. Wisata Syariah harus menjadi ikon kebangkitan budaya Islam, sekaligus maklumat bagi dunia bahwa di dunia Islam juga terdapat objek-objek wisata yang mengagumkan sebagai bentuk warisan budaya. Dengan adanya wisata Syariah ini, maka masyarakat dunia diperkenalkan terhadap keluhuran dan kebesaran dunia islam.

Dengan memaklumatkan kebudayaan Islam maka otomatis ada upaya untuk menyebarkan nilai-nilai Islam. Wisata bukan sekadar untuk menjadi ajang hiburan melainan juga sarana dakwah Islamiyah, sehingga para turis dapat mengenal lebih jauh Islam yang indah, damai, dan mengagumkan. Rekreasi pun menjadi bukan sekadar pemuasan ragawi melainkan juga media ibadah yang mengandung pahala. Dengan prinsip memperkenalkan budaya Islam dan menyebarkan ajaran-ajarannya maka wisata Syariah dapat dibenarkan secara teoritis dan perlu dikembangkan secara praktis.

Kedua, Abdel-Sahib mengatakan bahwa wisata Syariah harus mendatangkan keuntungan ekonomi bagi masyarakat Muslim tentu saja ini adalah tujuan pragmatis yang tidak boleh dilupakan. Namun, di dalam tujuan pragmatis semacam itu terdapat idealism yang mulia, yakni kepedulian pada peningkatan kesejahteraan umat muslim, yang dalam konteks ini mereka menjadi host. Artinya, wisata Syariah dikembangkan dengan tujuan untuk meningkatkan kesejahteraan umat Muslim.

Ketiga, Abdel-Sahib Al-Shakry menginginkan supaya wisata Syariah tersebut 
dapat menguatkan kepercayaan diri, identitas, dan keyakinan umat Muslim dalam menghadapi stereotip negative disbanding kebudaaan dan gaya hidup budaya lain. Artinya, berwisata bukan sekadar berbisnis, melainkan juga gaya hidup, standard prestise suatu kelompok masyarakat. Suatu bangsa dan negara yang memiliki perhatian tinggi terhadap pengembangan objek wisata dapat dikategorikan sebagai bangsa dan negara yag maju. Sebaliknya, negara yang miskin objek wisata akan terkubur di antara sampah-sampa peradaban dunia.

Dari paparan di atas, kita dapat memahami maksud konsep wisata Syariah yang ditawarkan oleh Al-Shakry. Konseptualisasinya terangkum dalam tiga poin utama: ekonomi, budaa dan agama. Pariwisata tntu ditujuan sebagai dunia bisnis yang halal dan mendatangkan keuntungan finansial bagi umat Muslim. Pariwisata juga dapat dijadikan media mempromosikan dan memperkenalkan budaya-budaya Islam. Terakhir, kepentingan wisata syariah adalah untuk menyebarkan nilai dan ajaran Islam.

Berdasarkan konsep wisata Syariah yang ditawarkan oleh Al-Shakry yang menggabungkan 3 sektor yang bisa dicakup meliputi: ekonomi, budaya dan agama, di Pemlang terdapah salah satu desa dengan nama Surajaya yang letaknya tidak jauh dari pusat Kabupaten Pemalang. Surajaya dikenal sebagai desa wana wisata yang menghadirkan pemandangan indah khas asri pedesaan. Destinasi yang menjadi tujuan utama wisatawan adalah makam Pangeran Purbaya Siranjaya. Makam tersebut sudah ada sejak tahun 1676 yang diyakini merupakan makam Pangeran Purbaya yang berasal dari Kerajaan Mataram Islam.

Pengelolaan terhadap destinasi wisata Syariah ini dibawah naungan Badan Usaha Milik Desa (Bumdes). Tujuan pembangunan wisata Syariah ini awalnya untuk meningkatkan ekonomi rakyat di Desa Surajaya, letak desa ini di tepi hutan, yang masyarakatnya sangat bergantung terhadap hasil hutan yang merupakan salah satu hutang lindung. Terdapat tiga jenis paket wisata yang diperuntukkan untuk wisatawan, meliputi wisata edukasi, wisata religi dan wisata budaya.

Selain desa Surajaya terdapat juga desa wisata syariah lain yang memadukan konsep wisata alam budaya, yaitu wisata Penggarit Kecamatan Taman. Desa ini juga menawarkan wisata religi di makam Pangeran Benowo yang dipadukan juga dengan adanya wahana alam budaya Benowo Park. Wisata Syariah di desa ini juga dikelola dan dikembangkan oleh Badan Usaha Milik Desa (Bumdes). Destinasi wisata ini juga menawarkan wisata perahu susur Sungai Waluh yang menghubungkan desa wisata Penggarit dngan desa wisata Pegongsoran. Selain itu, disajikan atraksi memberi makan monyet liar, memberi makan ikan, menembak hingga memanah. Festival juga sering digelar dipenggarit karena terhdapat juga 51 hektar lahan manga dan ribuan pohon manga yang hidup di pekarangan.

Dari konsep Al-Shakry dan contoh baik di desa Surajaya maupun desa Penggarit, kita dapat mempertimbangkan dan mengkalkulasi tentang peluang yang bisa dikembangkan terhadap wisata Syariah utamanya di Kabupatten Pemalang yang mayoritas penduduknya adalah Muslim. Ke depan Pemalang dapat memperkenalkan kebudayaan mereka dalam tampilah konsep wisata. Sehingga jika ditelaah tidak ada kendala konseptual untuk terus melangkah membangun, mengembangkan, dan mempromosikan objek-objek wisata berbasis religious. Berikut destinasi wisata Syariah yang ada di Kabupaten Pemalang:

Tabel 1. Destinasi objek wisata Syariah di Pemalang

\begin{tabular}{|l|l|}
\hline $\begin{array}{l}\text { Syekh maulana syamsudin di tepi pantai widuri, Desa widuri dan } \\
\text { kelurahan Sugihwaras }\end{array}$ & Syekh nurkalam, diibelakang msjid agung Pemalang \\
\hline Syekh jambukarang, di desa Karangbrei dan desa Wiyoro & Makam pangeran benowo dan ki gede jamur apu di desa penggarit \\
\hline Syekh salamudin dukuh Pedurungan barat & Pangeran mangoneng di kelurahan Bojongbata \\
\hline Syekh Pandanjati, di Desa bantarbolang & Pangeran purbaya di desa surajaya \\
\hline Mbah bantarbolang, di desa Bantarbolang & Candi alam gunung jimat di desa mendelem, Kecamatan Belik \\
\hline Mbah nur, di desa Walangsanga & Petilasan raden bahurekso dsa kesesirejo \\
\hline Pangeran kuning komplek candi di dekat SD Negeri 3 Pedurungan & $\begin{array}{l}\text { Sumur besalen sambungyudo dan patih sampun jiwonegoro, syekh } \\
\text { pangeran talabudin/kalamudin di dusun pedurungan tengah, Desa } \\
\text { Pedurungan }\end{array}$ \\
\hline
\end{tabular}




\begin{tabular}{|l|l|}
\hline $\begin{array}{l}\text { Syekh patih sampun , mbah depok di komplek makam depok } \\
\text { wanarejan utara }\end{array}$ & Petilasan candi/situs Plawangan di desa Lawang rejo \\
\hline Syekh cakramudin di wanarejan utara & Mbah sumberagung di dusun Caur \\
\hline Petilasan rakai panaraban gunung jimat mendelem belik & BPA. Buminata dan dadung ngawuk di desa Mandiraja, Moga \\
\hline $\begin{array}{l}\text { Ki gedhe majalangu Mertua patih sampun jiwonegoro1 di desa } \\
\text { pedurungan kulon }\end{array}$ & $\begin{array}{l}\text { Syekh pangeran kalamudin atau Patih Sampun jiwonegoro 1 di } \\
\text { desa pedurungan Tengah yang telah di pugar bupati Pemalang }\end{array}$ \\
\hline Petilasan ki gede tunggul manik di Dusun banjaran & Makam mbah haji taman di komplek makam taman \\
\hline Makam syek alif di desa taman & Candi rikmoilang di katangtalok \\
\hline Situs peradaban sepanjang kali comal & Situs atau candi sigeseng adipati kanjeng swargi di desa pesantren \\
\hline Petilasan syek maulana maghribi di desa Pesantren & Syeh Jambu Karang di Kendalrejo, Petarukan \\
\hline
\end{tabular}

Wisata Syariah ini jika ditelaah lebih lanjut dalam pengembangannya dapat menjadi suatu dual effek dalam bidang ekonomi atau yang sering dikenal sebagai ekonomi komersial ganda. Pembangunan wisata Syariah ini bisa diinteraksikan bersama dengan pembangunan ekonomi yang ada di Kabupaten Pemalang. Pembahasan ini harus menyertakan juga mengenai perspektif budaya ekonomi.

Perspektif budaya ekonomi merupakan suatu cara pandang yang digunakan untuk memahami pola tindakan dan pola pikiran para anggota masyarakat dalam mengorganisasi produksi, distribusi dan pertukaran barang atau jasa melalui di pasar. Pola tindakan dan pola pikiran merupakan pengulangan tindakan dan pengulangan pikiran manusia yang berlangsung terus menerus. Berger [14] mengemukakan dalam perspektif budaya ada dua keterkaitan logis dalam memahami fenomena ekonomi, yaitu intrinsic dan extrinsic linkage. Keterkaitan yang pertama menggambarkan keterhubungan antara dua variabel di mana variabel pertama sebaga prasyarat eksistensi variabel kedua, sedangkan sifat keterhbungan kedua lebiih cenderung karena kebetulan. Keterhubungan antara budaya dengan ekonomi bersifat timbal balik dan berlangsung secara simultan dlam suatu totalitas empiris. Hubungan kausalitas ersebut tidak diasumsikan bahwa budaya menentukan ekonomi atau sebaliknya ekonom determinan terhadpa budaya. Berger menjelaskan penelitian empiris tentang Lembaga-lembaga ekonomi akan menjelajahi konteks social budaya, di mana proses-proses ekonomi tertentu itu beroperasi. Lembagalembga ekonomi tidak berada dalam ruang hampa, melainkan berada dalam suatu konteks struktur social dan budaya. Maksudnya suatu teori komprehensif tentng Lembaga-lembaga ekonomi akan muncul melalui penelitian yang sistematis mengenai unsur-unsur budaya ekonomi yang saling terkait bersama dalam suatu totalitas empiris. Atau dengan kata lain, saling keterkaitan bersama antar unsur-unsur yang beropeasi dalam proses kelembagaan ekonomi.

Kabupaten Pemalang dalam memajukan budaya yang terkait dengan ekonomi memajukan salah satu produk yang berupa batik. Batik merupakan kesenian warisan nenek moyang kita. Seni batik mempunyai nilai seni yang tinggi, perpaduan seni dan teknologi. Batik menarik perhatian bukan semata-mata hasilnya, tetapi juga proses pembuatannya. Inilah yang kemudian membuat batik diakui oleh dunia. Menurut Kuswadji, batik berasal dari bahasa Jawa, "Mbatik", kata mbat dalam bahasa yang juga disebut ngembat. Arti kata tersebut melontarkan atau melemparkan. Sedangkan kata tik bisa diartikan titik. Jadi, yang dimaksud batik atau mbatik adalah melemparkan titik berkali-kali pada kain. Batik mulai berkembang pada zaman kerajaan Majapahit dan penyebaran Islam di Jawa. Pada mulanya, batik hanya dibuat terbatas oleh kalangan kraton. Hasilnya kemudian dipakai oleh raja dan keluarga serta para pengikutnya. Kemudian, batik dibawa keluar kraton oleh para pengikut raja. Dari sinilah kesenian batik kemudian berkembang di masyarakat [15].

Setiap motif batik mempunyai makna filosofis. Makna-makna tersebut menunjukkan kedalaman pemahaman terhadap nilai-nilai local. Dan, sampai sekarang nilai-nilai tersebut masih bertahan. Terpengaruh dari Kabupaten sekitar yaitu Kabupaten Pekalongan, Kota Pekalongan, dan Tegal yang lebih dahulu sudah memajukan dan dikenal sebagai penghasil batik yang memiliki corak tertentu yang mewakili budaya local setempat, Pemalang mengembangkan batik dengan corak yang mewakili budaya local Pemalang yaitu corak 
dengan motif Grombyang dan motif nanas. Batik ini dikembangkan dan dipromosikan sebagi batik grombyang dan batik nanas. Grombayang sendiri merupakan makanan khas yang terdapat di pemalang, makanan khas ini seringkali menjadi icon yang sering dikunjungi oleh public figure dan tokoh terkenal ketika berkunjung atau melewati kota Pemalang, sedangkan nanas sendiri merupakan perwujudan dari nanas madu belik pemalang yang sudah mulai tersebar di banyak wilayah.

Jika kita ingin memahami interaksi antara wisata Syariah dan perkembangan ekonomi di suatu daerah dalam wujud ekonomi komersial ganda maka kita harus memahami pendapat dan konsep yang diajukan oleh beberapa tokoh berikut: Polanyi [16] mengungkapkan kajian Lembaga-lembaga ekonomi bertitik tolak dari bentuk integrase perekonomian masyarakat, yaitu reciprocity, redistribution dan exchange. Perilaku timbal balik sebagai bentuk integrase perekonomian masyarakat terjadi jika terdapat struktur dan organisasi social yang setara, seperti dalam sistem kekeluargaan. Perilaku berbagi membentuk integrasi perekonomian masyarakat, terjadi bila terdapat alokasi barang pada suatu pusat dengan mekanisme distribusi berlangsung menurut adat. Perilaku tukar-menukar merupakan bentuk integrasi perekonomian masyarakat, tejadi jika terdapat mekanisme sistem pasar. Secara tegas Polanyi membedakan bahwa perilaku timbal balik dan perilaku berbagi sebagai bentuk integrasi perekonomian suatu masyarakat berciri ekonomi subsistem sedangkan peilaku tukar menukar melalui sistem pasar dapat ditemui pada masyarakat berciri ekonomi komersial. Pasar dipahami sebagai institusi yang superior terhadpa institusi social lainnya. Pasar berjalan atas logika selfregulating market melepaskan diri dari ikatan-ikatan social budaya. Keeradaan ekonomi komersial menjadi dterminan dalam seluruh proses social.

\footnotetext{
Pariwisata dan ekonomi memiliki keterkaitan yang kuat, seiring berkembangnya pariwisata di suatu daerah sangat memungkinkan untuk berkembangnya perekonomian di daerah tersebut. Hubungan keduanya saling melengkapi, ekonomi akan tumbuh jika ditopang oleh perkembangan wisata yang semakin maju, terutama bagi
}

pelaku usaha sekitar destinasi wisata, baik pelaku usaha kecil, menengah, maupun yang besar. Menurut Cooper (2005) [17] model ekonomi pariwisata ada tiga unsur yang terkait, yaitu: 1) konsumen dalam hal ini adalah wisatawan; 2) mata uang yang beredar sebagai unsur dalam transaksi ekonomi; 3) adanya barang dan jasa dari sektor ekonomi. Hipotesis menarik yang dikemukakan oleh Muhammad Afdi Nizar tentang hubungan antara pariwisata dan ekonomi yang kausalitas, yakni: a) pertumbuhan ekonomi ditopang oleh pariwisata, maka dari itu pertumbuhan ekonomi dipengaruhi oleh perkembangan pariwisata (tourism-led economic growth hypothesis); b) pariwisata ditopang oleh ekonomi, sehingga perkembangan wisata dipengaruhi oleh pertumbuhan ekonomi (economic-driven tourism hypothesis); c) keduanya (ekonomi dan pariwisata) memiliki manfaat satu sama lain dan bersifat dua arah (reciprocal causal hypothesis). Lalu, Nizar berpendapat bahwa ada dua hal yang membangun adanya hubungan antara pariwisata dan ekonomi, yakni: 1) pariwisata berdampak pada ekonomi karena dapat menciptakan lapangan kerja, berpengaruh terhadap pendapatan, neraca pembayaran, penerimaan devisa dari beberapa hal, seperti belanja wisatawan, pembangunan pariwisata, impor maupun ekspor barang dan lain-lain; 2) pariwisata dapat menjadi efek stimulus bagi produkproduk tertentu dan dapat membentuk komunitas-komunitas yang diharapkan hal tersebut dapat menggerakkan ekonomi daerah ke arah yang positif dengan diciptakannya lapangan kerja baru dan meningkatnya pendapatan bagi daerah [18].

Boeke [19] menggambarkan perkembangan ekonomi di Indonesia dengan tesis dualism ekonomi. Boeke membagi masyarakat ekonomi menjadi sector modern yang kapitalistik dengan sector tradisional yang pra kapitalistik. Senada dengan tesis dualism ekonomi, kajian Mynt [20] menegaskan dikotomi sector ekonomi modern dengan sector ekonomi tradisional sebagai berikut: a) Unit-unit usaha dalam sector ekonomi modern sangat terspesialisasi dan terintegrasi penuh. Sebaliknya unit-unit usaha pada sector ekonomi tradisional mempunyai derajat spesialisai yang rendah, b) sector ekonomi modern mencakup usaha- 
usaha besar yang padat modal dengan teknologi yang modern, sementara sector ekonomi tradisional mencakup usaha-usaha kecil dengan teknologi tradisional. C) usaha bisnis di sector modern mempekerjakan tenaga kerja berdasarkan spesifikasi kerja, sebaliknya di sektor tradisional menyeap tenaga kerja keluarga, d) usaha bisnis di sector modern mempunyai akses ke Lembaga keuangan formal dengan bunga rendah, sebaliknya usaha bisnis di sector tradisional cenderung akses Lembaga ekonomi non formal dengan Bunga tinggi.

Dalam perspektif yang berbeda, Ranis [21] menyatakan dualism ekonomi sebuah kontinum karena sector modern mempunyai hubungan dengan sector tradisional. Bahkan ditegaskan bahwa sector modern sebagai kelanjutan dari sector tradisional. Menurut Ranis bahwa tenaga kerja yang berlebih sudah sedemikian besar di sector ekonomi tradisional dan sector ekonomi modern tidak mempunyai kapasitas yang cukup untuk menyerapnya. Persoalan pada sector ekonomi tradisional itu sendiri semakin rumit, smentra itu perkembangan sector ekonomi modern semakin mapan karena mengimbangi perkembangan yang pesat diluarnya. Akibatnya keterkaitan sector ekonomi tradisional dan sector ekonomi modern tidak fungsional.

Model keterkaitan (linkages) antar sector dan di dalam suatu sector digunakan untuk menjelaskan proses industrialisasi. Model keterkaitan di dalam sector melalui keterkaitan keruangan antar daerah terbentuk karena ada kerja sama dalam hubungan antara peusahaan di suatu tempat dengan perusahaan tempat lain. Perkembangan kerja sama dalam hubungan keruangan antar daerah tersebut akan merangsang industrialisasi di sector jasa.

Menurut IUOTO (International Union of Official Travel Organization) ada delapan alasan sektor pariwisata harus dikembangkan, antara lain: a. Pariwisata sebagai faktor dorongan dalam pertumbuhan ekonomi nasional maupun internasional. b. Sektor pariwisata bisa mendorong kemakmuran melalui kemajuan komunikasi, transportasi, akomodasi, jasa-jasa pelayanan. c. Terjadi perlindungan budaya, nilai sosial agar bernilai ekonomi d. Pemerataan kesejahteraan yang diakibatkan oleh adanya konsumsi wisatawan pada destinasi. e. Dapat menaikkan devisa negara. f. Mendorong perdagangan international. g. Mendorong peningkatan dan perkembangan lembaga profesi pariwisata. h. Meningkatkan pasar bagi produk local.

Semakin meningkatnya kunjungan wisatawan ke daerah tersebut akan berpengaruh positif terhadap pendapatan masyarakat, karena semakin tingginya permintaan barang dan jasa sehingga tercipta lapangan kerja untuk masyarakat. Meningkatnya pendapatan akan berpengaruh terhadap kesejahteraan masyarakat. Ukuran pendapatan diukur untuk melihat tingkat kesejahteraan rumah tangga menggunakan pendapatan yang diperoleh dari bekerja [22].

Monge [23] mengemukakan reticulum sebagai suatu jaringan social personal yang dibangun atas prakarsa dan kepentingan egosentris individu. Jaringan personal yang digunakan secara terus menerus dan berulang ulang akan membentuk suatu pola yang mantap, permanen, dan berkesinambungan dinamakan sebagai suatu klik. Monge mengungkapkan analisis jaringan personal atau analisis klik berlangsung melalui hubungan relasional antara star, laison dan members. Posisi pusat (star) sebagai pemrakarsa memanfaatkan perantara (liason) untuk mengontrol anggota (members) guna memenuhi kepentingan egonya.

Dalam konteks jaringan hubungan relasional antar industry dapat berlangsung melalui keterkaitan keruangan antara industry di suatu daerah dengan industry di daerah lain dan keterkaitan vertical antara industry besar dengan industry kecil. Dinamika keterkaitan vertical dengan keterkaitan antar ruangan tersebut menumbuhkan jaringan social ekonomi makin panjang dan beragam. Kompleksitas jaringan social ekonomi tersebut dapat membentuk pola bonding social capital atau pola bridging social capital. Kompleksitas jaringan social ekonomi yang terbentuk melalui keterkaitan antar keruangan dan keterkaitan vertical antara industry di suatu daerah dengan industry di daerah lain cenderung membentuk pola bridging social capital. Sebaliknya jaringan social ekonomi yang terbentuk melalui keterkaitan vertical antar 
industry di dalam suatu ruangan derah tertentu cenderung membentuk pola bonding social capital.

Perekmbangan perekonomian dalam masyarkat industry ditandai dengan ekonomi komersial ganda, antara mode produksi industry rumah tangga berbasis ekonomi komersial yang berorientasi pada pemenuhan konsumsi dengan mode produksi pabrikan dan manufaktur berbasis ekonomi komersial berorientasi pada pengembangan produksi. Kedua mode produksi tersebut memiliki mekanisme ekonomi sendiri-senfiri tetapi kedua mode produksi tersebut saling terkait satu sama lain. Keterkaitan antara mode produksi industry rumah tangga yang berorientasi pada pemenhan konsumsi dengan pabrikan/manufaktur yang berorientasi pada pengembangan produksi berlangsung dengan pola mutualisma dan pola eksploitasi.

Sebaliknya teori eksistensi dualism ekonomi menjelaskan hubungan antara sector ekonomi tradisional dengan sector ekonomi modern merupakan hbuungan dominasi. Sector ekonomi modern mendominasi sector ekonomi tradisional. Hubungan dominasi antara sector ekonomi modern terhadap ekonomi tradisional bersifat eksploitasi. Hubungan dominasi sector ekonomi modern terhadap ekonomi tradisional menghasilkan suatu kondisi statis pada sector ekonomi tradisional.

Pemahaman dari beberapa konsep dan gagasan diatas maka jelas sekali bahwa terdapat interaksi yang sangat erat antara wisata Syariah dan pembangunan ekonomi disuatu daerah melalui ekonomi komersial ganda. Seperti kita pahamkan dari beberapa hal yang dijadikan dasar dalam wisata Syariah.

Ada banyak dalil Al-Quran maupun Sunnah Nabi yang berkaitan dengan pariwisata ini, berikut ini dalil-dalil normative dalam Islam tentang pariwisata:

- QS Al-An'am: 11

"Katakanlah: 'Berjalanlah di muka bumi, kemudian perhatikanlah bagaimana kesudahan orang-orang yang mendustakan itu."
- QS An-Naml: 60

"katakanlah: 'Berjalanlah kamu (di muka) bumi, lalu perhatikanlah bagaimana akibat orang-orang yang berdosa."

Saking pentingnya melakukan perjalanan di muka bumi ini (melancong) dengan tujuan untuk mencari pelajaran dan hikmah, Allah SWT mengulangi ayat yang nyaris sama di surah yang berbeda. Pada ayat pertama, Allah menganjurkan manusia agar melakukan perjalanan di muka bumi ini guna menemukan jawaban dan bukti bahwa orangorang yang mendustakan kebenaran Tuhan ditimpa azab yang pedih. Pada ayat berikutnya, Allah menganjurkan manusia untuk melakukan perjalanan guna menemukan jawban dan bukti bahwa hidup orang-orang yang berdosa berakhir deengan malang. Intinya, melancong atau berwisata memiliki tujuan spiritual, yakni untuk meningkatkan keimanan kepada Tuhan dan mengakui kebesarannya.

Dalam kitab Mahasinu At-Ta'wil. AlQasimi rahimahullah berkata: "Mereka berjalan dan pergi ke beberapa tempat untuk melihat berbagai peninggalan sebagai nasihat, pelajaran, dan manfaat lainnya." Tidak hanya untuk mencari hikmah kehidupan, berwisata dianjurkan oleh Islam dengan tujuan untuk mengagumi keindahan alam, supaya jiwa menjadi tenang. Wisata dalam Islam adalah sebuah safar atau traveling untuk merenungi keindahan ciptaan Allah SWT, menikmati keindahan alam untuk menguatkan keimanan dan memotivasi diri untuk terus menunaikan kewajiban hidup. Refreshing sangat diperlukan oleh jiwa agar selalu tumbuh semangat baru. Allah SWT berfirman: "Katakanlah: "Berjalanlah di (muka) bumi, maka perhatikanlah bagaimana Allah menciptakan (manusia) dari permulaannya, kemudian Allah menjadikannya sekali lagi. Sesungguhnya Allah Maha Kuasa atas segala sesuatu." (QS Al-Ankabut: 20).

Kabupaten Pemalang di kenal juga mempunyai banyak produk unggulan seperta Sentra tenun ATBM, konveksi, kerajinan kulit ular, dan sapu glagah, dan masih banyak potensi yang bisa di gali di bumi Pemalang tersebut. Kandungan sumber daya alam yang 
paling potensial di Kabupaten Pemalang khususnya pemalang bagian selatan yang terletak di lereng Gunung Slamet adalah berupa Tambang Diorit, Kaolin, Batu Gamping, dan Batu Marmer. Kegiatan ekonomi rakyat yang menjadi andalan di Kabupaten Pemalang adalah industri kecil pakaian jadi atau konveksi dan salah satunya adalah masuknya investor dari Jepang dengan mendirikan pabrik garment untuk memenuhi kebutuhan ekspor tekstil Indonesia. Hasil industri tesktil dan tenun meliputi sarung tenun, sarung palekat, kaos kaki dan goyor. Sementara itu kerajinan gerabah, sapu glagah, kerajinan kulit ular juga telah mampu menembus pasaran ekspor ke singapura dan Malaysia.

Wisata Syariah dapat dijadikan sebagai sarana dalam melakukan promosi terhadap potensi yang ada di Kabupaten Pemalang terkait dengan pembangunan ekonominya. Potensi yang meliputi baik industri rumah tangga atau industry rumahan maupun industry menengah atau besar merupakan bekal dasar dalam melakukan suatu interaksi tersebut. Pada intinya berdasarkan dari pendapat dari pakar-pakar diatas dalam melakukan pembangunan ekonomi maupun wisata harus terdapat keterkaitan yang erat.
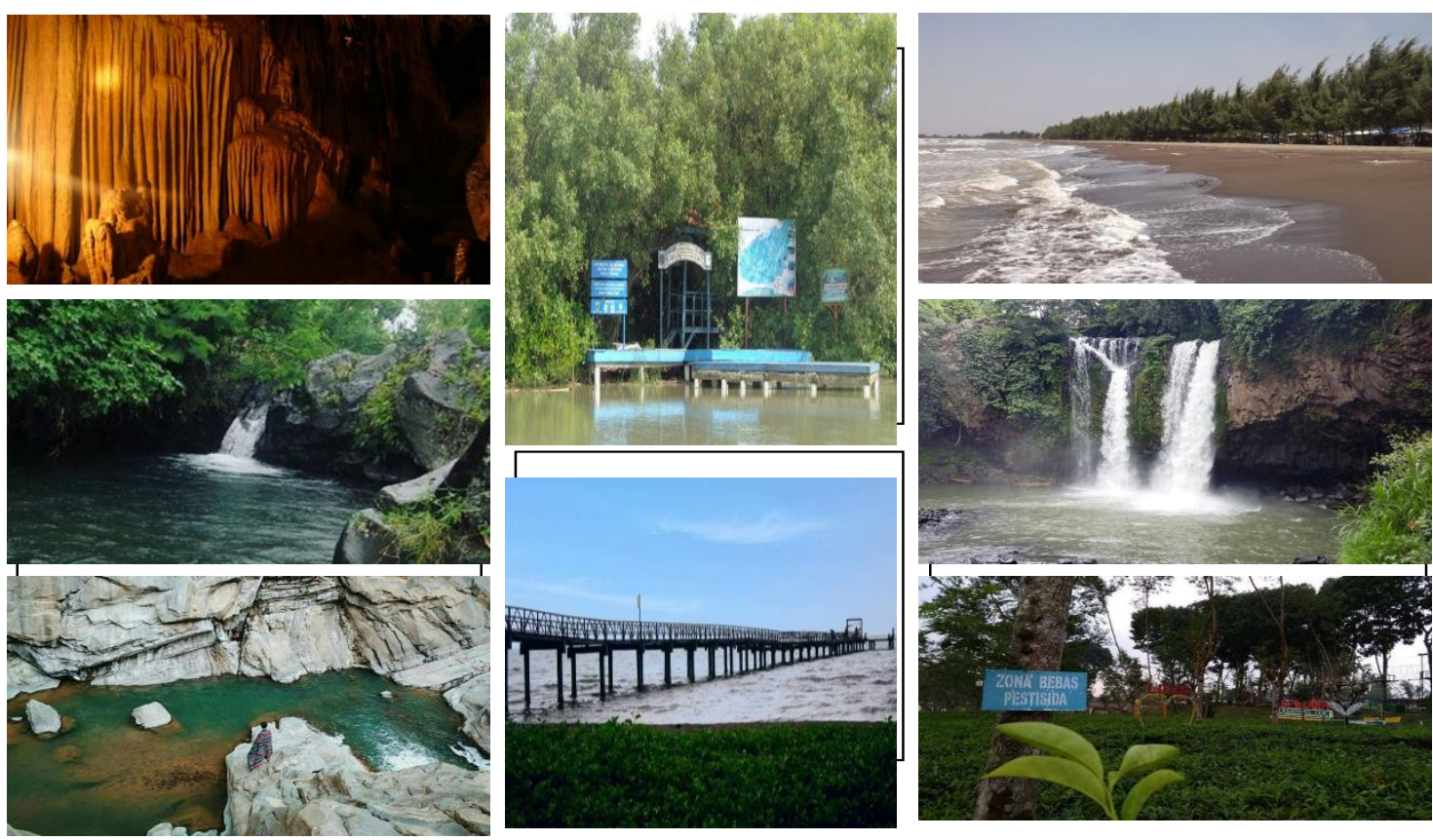

Gambar 1. Destinasi Wisata di Pemalang

Pariwisata memerlukan prose-proses yang kreatif dalam pengembangannya. Tahapan proses yang baik dalam pengembangan ini meliputi perencanaan, promosi, paket dan perjalan wisata, dan destinasi wisata itu sendiri. Tahapan ini memerlukan pertimbangan aktivitas yang kaya akan ide dan kreasi sehingga indutri pariwisata ini memiliki hubungan timbal balik dengan indutri kreatif. Industri kreatif adalah industriyang berasal dari pemanfaatan kreativitas, keterampilan serta bakat individu untuk menciptakan kesejahteraan serta lapangan pekerjaan dengan menghasilkan dan mengeksploitasi daya kreasi dan daya cipta individu tersebut. Industri kreatif dipandang semakin penting dalam mendukung kesejahteraan dalam perekonomian karena di jaman sekarang akan tergantung pada produksi pengetahuan melalui kreativitas dan inovasi

\section{Kesimpulan}

Wisata Syariah harus dipahami sebagai konsep keagamaan dan kebudayaan, di mana tujuan-tujuan islami, ajaran-ajaran Islam, serta kaidah dan akidan Islamiyah harus dimasukkan dan dijadikan program-program yang ditawarkan dalam aktivitas wisata Sariah tersebut. Artinya, wisata Syariah tidak sekadar untuk memindahkan aktivitas para turis ke area kita, melainkan juga kita bisa menawarkan nilai-nilai keagamaan dan kebudayaan kita kepada mereka. Sector wisata Syariah yang teintegrasi dengan 
pembangunan ekonomi memiliki kontribusi yang positif dalam meningkatkan perekonomian suatu daerah yang diwujudkan dalam efek tumpah berupa ekonomi komersial ganda. Wisata Syariah tidak hanya sebagai implementasi perwujudan dari nuansa religiusitasyang tercakup di dalam aspek mu'amalah sebagai pengejawantahan aspek kehidupan sosial budaya dan sosial ekonomi yang berlandaskan prinsip-prinsip Syariah, namun juga harus mendatangkan keuntungan ekonomi bagi masyarakat Muslim tentu saja ini adalah tujuan pragmatis yang tidak boleh dilupakan. Namun, di dalam tujuan pragmatis semacam itu terdapat idealism yang mulia, yakni kepedulian pada peningkatan kesejahteraan umat mslim, yang dalam konteks ini mereka menjadi host. Artinya, wisata Syariah dikembangkan dengan tujuan untuk meningkatkan kesejahteraan umat Muslim.

\section{References}

[1] Ramadhany, Fitratun., Ridlwan, Ahmad Ajib. 2018. Implikasi Pariwisata Syariah Terhadap Peningkatan Pendapatan Dan Kesejahteraan Masyarakat. Muslim Heritage. 3. 1:147-164.

[2] Adinugraha, Hendri Hermawan et al. 2018. Desa Wisata Halal: Konsep Dan Implementasinya $\mathrm{Di}$ Indonesia. Human Falah. 5. 1:28-48.

[3] Syahriza, Rahmi. 2014. Pariwisata Berbasis Syariah: Telaah Makna Kata Sara dan Derivasinya dalam al-Qur'an. Jurnal Human Falah. 1. 2:135-145.

[4] Masful, Mila Falma. 2017. Pariwisata Syariah: Suatu Konsep Kepercayaan dan Nilai Budaya Lokal Di Daerah Pedalaman Pilubang, Payakumbuh, Sumatera Barat. The Messenger. 9. 1:1-8.

[5] Al Hasan, Fahadil Amin. 2017. Penyelenggaraan Parawisata Halal di Indonesia: Analisis Fatwa DSN-MUI tentang Pedoman Penyelenggaraan Pariwisata Berdasarkan Prinsip Syariah. AlAhkam: Jurnal Ilmu Syariah dan Hukum. 2. 1:59-78.

[6] Satriana, Eka Dewi., Faridah, Hayyun Durrotul. 2018. Wisata Halal: Perkembangan, Peluang, dan Tantangan. Journal of Halal Product and Research (JHPR). 1. 2:32-43.
[7] Rimet. 2019. Strategi Pengembangan Wisata Syariah Di Sumatera Barat: Analisis Swot (Strength, Weakness, Opportunity, Threath. Syarikat: Jurnal Rumpun Ekonomi Syariah. 2. 1:50-61.

[8] Sucipto, Hery., Andayani, Fitria. 2014. Wisata Syariah. Grafindo Book Media. Jakarta.

[9] Antariksa, Basuki. 2016. Kebijakan Pembangunan Kepariwisataan. Intrans Publishing. Malang.

[10] Widagdyo, Kurniawan Gilang. 2015. Analisis Pasar Pariwisata Halal Indonesia. The Journal of Tauhidinomics. 1. 1:73-80.

[11] Jaelani, Aan. 2017. Halal tourism industry in Indonesia: Potential and Prospects. Munich Personal RePEc Archive. Paper No. 76237.

[12] Sofyan, Riyanto. 2012. Prospek Bisnis Pariwisata Syariah. Republika. Jakarta.

[13] Ranis, Gustav. 1984. The Dual Economy Framework Relevance Asia Development. Manila Asia Development Review. 2. 1:3951.

[14] Berger, Peter L. 1990. Revolusi Kapitalis. LP3Es. Jakarta.

[15] Tim Sanggar Batik Barcode. 2010. Batik. Katabuku. Jakarta.

[16] Polanyi. 1957. The Great Transformation. Peacon Press. Boston.

[17] Remi, S. S., Waluyo, S. D., Muljarijadi, B. 2016. Peran Pariwisata Dalam Perkembangan Perekonomian Daerah Studi Kasus Provinsi DKI Jakarta. Fakultas Ekonomi Universitas Padjadjaran Ikatan Sarana Ekonomi Indonesia. 1-22.

[18] Nizar, M. A. 2011. Pengaruh Pariwisata Terhadap Pertumbuhan Ekonomi Di Indonesia. Jurnal Kepariwisataan Indonesia. 6. 2:195-211.

[19] Boeke, J. H., Burger, D. H. 1973. Ekonomi Dualistik: Dialog Antara BOeke dan Burger. Bharatara. Jakarta.

[20] Mynt, Hilla. 1985. Organizational Dualism and Economic. Asian Development Review. 3. 1.

[21] Ranis, Gustav. 1984. The Dual Economy Framework Relevance Asia Development. Asia Development Review. 2. 1:39-51.

[22] Zakiyah., Maulida, Atika Zahra. 2017. Analisis Strategi Evaluasi Kinerja Pengentasan Kemiskinan Dalam Program Pembangunan Desa Perspektif Ekonomi 
Mikro Islam. Al-Uqud: Journal of Islamic Economics. 1. 2:1-13.
[23] Monge, Peter R. 1987. The Network Level of Analysis. Sage Publications Inc. 